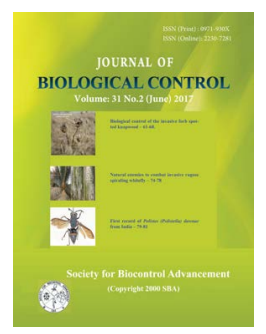

\title{
Effect of TNAU-Pf1 seed biopriming and foliar spray of newer fungicides on the incidence of leaf blight of sunflower
}

\author{
L. RAJENDRAN ${ }^{*}$, C. GOPALAKRISHNAN ${ }^{1}$, T. SELVAKUMAR ${ }^{2}$, N. MANIVANNAN ${ }^{3}$ and P. L. VISWANATHAN ${ }^{4}$ \\ ${ }^{\prime}$ Plant Pathology, TNAU, Coimbatore - 3, Tamil Nadu, India \\ ${ }^{2}$ Agronomy, TNAU, Coimbatore - 3, Tamil Nadu, India \\ ${ }^{3} P B G$, TNAU, Coimbatore - 3, Tamil Nadu, India \\ ${ }^{4}$ Department of Oilseeds, TNAU, Coimbatore - 3, Tamil Nadu, India \\ ${ }^{*}$ Corresponding author E-mail: rucklingraja@gmail.com
}

\begin{abstract}
Seed biopriming followed by foliar spray of different newer fungicide molecules to manage sunflower leaf spot under field conditions have been tried in Coimbatore, Tamil Nadu, India for three consecutive years (2014-2016). The result indicated that among the different treatments tested, seed biopriming with TNAU Pseudomonas fluorescens (Pf1) @ 10g/kg seeds followed by spray of Hexaconazole @ $0.1 \%$ at 45 days and P. fluorescens (Pf1) @ 1.0\% at 60 DAS showed less severity of Alternaria leaf spot (25.7) with the highest yield of $1471 \mathrm{~kg} / \mathrm{ha}$ against the control (47.7) which recorded yield of $1111 \mathrm{~kg} / \mathrm{ha}$. In addition, seed biopriming promoted higher and uniform seed germination under field conditions.
\end{abstract}

KEY WORDS: Newer molecule, leaf spot/blight, seed biopriming, seed yield, sunflower

(Article chronicle: Received: 25.05.2017; Revised: 22.06.2017; Accepted: 28.06.2017

\section{INTRODUCTION}

Sunflower (Helianthus annuus L.) is the third most important edible oil seed crop worldwide and is cultivated over an area of 2.4 million hectares with the productivity of $608 \mathrm{~kg} / \mathrm{ha}$ in India. Among the different growing states, Karnataka, Andhra Pradesh, Maharashtra, Tamil Nadu, Bihar, Punjab, Haryana and Uttar Pradesh are important. During the crop growth period, it is infected by more than thirty diseases (Gulya et al.,1994). Among the various diseases, necrosis, leaf spot or blight occurs in early stages and powdery mildew which occurs in later stages are most important as they cause drastic yield losses (25-40 per cent) under field conditions (Shankergoud et al., 2006; Chander Rao et al., 2015). Within the diseases, leaf spot or blight caused by Alternaria helianthi (Hansf.) Tubaki \& Nishihara is a serious and potentially destructive one causing premature defoliation favored by higher relative humidity and warm temperature (Prathuangwong et al. 1991; Wang et al., 2014). The damages are due to the formation of leaf spots, reduction of plant photosynthetic area and early defoliation (Leite et al., 2006; Alves et al., 2013). Further, the leaf spot or blight significantly reduces head diameters, seed numbers, 1000-seed weight and oil percentage (Balasubrahmanyam and Kolte 1980; Reddy and Gupta 1977). Until now, there is no resistant variety or hybrid available against leaf spot or blight disease, also an efficient disease management system is not available for suppressing the disease during an epidemic. Hence, use of fungicides become inevitable. In the present study, to manage the leaf spot or blight, seed biopriming with TNAU-Pf1 and foliar spray of different newer molecules have been tried under field conditions to reduce the excess and repeated use of fungicide. Seed priming often results in more rapid and uniform seedling emergence and may be useful under adverse soil conditions (Mathre et al., 1994). Besides controlling the pathogen, seed-borne infections of $A$. helianthi are controlled by Pseudomonas fluorescens seed treatment which showed least seed infection, higher root and shoot length in sunflower (Ahila Devi et al., 2014). Hence, in the present study, bio priming along with newer fungicide molecule foliar spray have been tested under field conditions to find out their efficacy against the leaf blight disease.

\section{MATERIALS AND METHODS}

\section{Field and soil conditions}

The field trials were conducted at the Department of Oilseeds, TNAU, Coimbatore, Tamil Nadu, India during the season kharif, 2014, 2015 and 2016. The field experiment was laid out in randomized block design with four replications with the plot size of $4.2 \mathrm{~m} \times 3.0 \mathrm{~m}$ with the spacing 
of $60 \times 30 \mathrm{~cm}$. The performed experiment site is low in nitrogen, phosphorus content and medium in nutrient potash. As per the TNAU crop production guide recommendation, nutrients were applied to the soil. The soil was red loam in texture with the $\mathrm{pH}$ of 6.7. For the better germination of crop, sowing was taken up in 5-7 cm soil depth.

\section{Talc-based bioformulation TNAU-Pf1}

The talc-based bio-formulation of Pseudomonas fluorescens was prepared with some modification (Vidhyasekaran and Muthamilan, 1995). At the time of use, the $P$. fluorescens population in the formulation was $3 \times 10^{8}$ $\mathrm{cfu} / \mathrm{g}$ talc powder.

\section{Bio priming with TNAU-Pf1}

The sunflower hybrid CO 2 was used for the field evaluation. Sunflower seeds were surface sterilized with $1.5 \%$ $\mathrm{NaOCl}$ for 5 minutes and pre soaked in sterile water for 12 hrs, the seeds were treated with TNAU P. fluorescens Pf1 @ $10 \mathrm{~g} / \mathrm{kg}$ and incubated in moist blotter for $48 \mathrm{hrs}\left(25-32^{\circ} \mathrm{C}\right)$ and used for sowing.

\section{Newer molecule and disease assessment}

After seed biopriming, foliar spray was given at 45 and 60 days after sowing as per the treatment mentioned below. Observations on seed germination and disease severity in Per cent Disease Index (PDI) were recorded as per the formula mentioned below. Totally thirty individual leaves were observed per treatment per replication. Newer fungicide molecules namely Hexaconazole, Propiconazole, Tebuconazole and fungicide chlorothalanil were purchased from private agency.

The treatment details were

T1 - SB with Pseudomonas fluorescens (Pf1) @10g/ $\mathrm{kg}$ seeds followed by two sprays of P. fluorescens (Pf1) @ $1.0 \%$ at 45 and 60 DAS

T2 - SB with Pseudomonas fluorescens (Pf1)@10g/ $\mathrm{kg}$ seeds followed by spray of Hexaconazole @ $0.1 \%$ at 45 days and P. fluorescens (Pf1) @ 1.0\% at 60 DAS

T3 - SB with Pseudomonas fluorescens (Pf1)@10g/ $\mathrm{kg}$ seeds followed by spray of Propiconazole @ $0.1 \%$ at 45 days and P.fluorescens (Pf1) @ 1.0\% at 60 DAS

T4 - SB with Pseudomonas fluorescens (Pf1) @10g/ $\mathrm{kg}$ seeds followed by spray of Tebuconazole @ $0.1 \%$ at 45 days and P. fluorescens (Pf1) @ 1.0\% at 60 DAS

T5 - SB with Pseudomonas fluorescens (Pf1) @10g/ $\mathrm{kg}$ seeds followed by spray of chlorothalanil @ $0.2 \%$ at 45 days and P. fluorescens (Pf1) @ 1.0\% at 60 DAS

T6 - Control

SB: seed biopriming and DAS: days after sowing

Per cent Disease Index (PDI) was calculated by using the formula given by Wheeler (1969).

PDI $\frac{\text { Sum of individual disease ratings }}{\text { Total number of leaves observed }} \times \frac{100}{\text { Maximum disease grade }}$

Alternaria leaf spot/blight

0 : Leaf showing no symptoms

1: Scattered brown spots covering $1 \%$ or less of the leaf area which is small and circular

3: Dark brown enlarging spots covering $1-10 \%$ of leaf area

5: Dark brown spots enlarging, target like appearance covering $11-25 \%$ of leaf area

7: Dark brown spots coalescing with target like appearance covering $26-50 \%$ of leaf area

9: Uniformly dark brown spots, coalescing covering $51 \%$ or above of leaf area

\section{Seed yield}

At the time of harvest, sunflower head from all treatments were weighed as per the replications separately and average weight was calculated. After threshing and winnowing, seed weight of each replication in kilogram was recorded and yield per hectare was computed by using net plot yield data.

\section{Statistical analysis}

The data were statistically analyzed using the IRRISTAT version 92 developed by the International Rice Research Institute Biometrics unit, the Philippines (Gomez and Gomez 1984). The percentage values of the disease index were arcsine transformed. Data were subjected to ANOVA at significant level $(\mathrm{p}<0.05)$ and means were compared by DMRT.

\section{RESULTS AND DISCUSSION}

Sunflower (Helianthus annuus L.) is one of the important oilseed crops in the world and it ranks third in area after soybean and groundnut and it is most susceptible to Alternaria helianthi which cause seedling blight, reduces crop stand and can infect both leaves and stems during anthesis and seed filling stage (Jeffrey et al., 1984). This symptom 
appears more frequently on older leaves than on young and expanding ones (Balasubramanyam and Kolte 1980). To manage, spraying of broad spectrum fungicide mancozeb has been recommended by several workers (Ramakrishnan et al., 1971; Stevenson 1977). Hence, to avoid the repeated use of fungicide with higher doses, the present study was carried out to test whether the bioagent seed priming and one foliar spray with newer fungicide molecule will help in managing the disease. In the present study, first season field experiment was started during the year 2014, among the different treatments tested, seed treatment with Pseudomonas fluorescens (Pf1) @ $10 \mathrm{~g} / \mathrm{kg}$ seeds followed by foliar spray of Hexaconazole @ $0.1 \%$ at 45 days and P. fluorescens Pf1@1.0\% at 60 DAS (T2) have recorded lowest incidence of Alternaria leaf spot (8.9 PDI) with the highest yield of $1194 \mathrm{~kg} / \mathrm{ha}$ which is statistically on par with T4 (the seed treatment with P. fluorescens Pf1 @ $10 \mathrm{~g} / \mathrm{kg}$ seeds followed by spray of Tebuconazole @ $0.1 \%$ at 45 days and P. fluorescens Pf1 @ 1.0\% at 60 DAS) when compared to control which recorded 20.8 PDI with the yield of $965 \mathrm{~kg} /$ ha (Table 1).

Table 1. Management of Alternaria leaf spot/blight through bioagents and fungicides in sunflower -Kharif 2014

\begin{tabular}{|l|l|l|l|}
\hline Treatments & $\begin{array}{l}\text { Disease severity } \\
(\text { PDI })\end{array}$ & Yield $(\mathrm{kg} / \mathrm{ha})$ & B:C ratio \\
\hline T1 & $9.9^{\mathrm{a}}$ & 1178 & 2.05 \\
\hline T2 & $8.9^{\mathrm{a}}$ & 1194 & 2.03 \\
\hline T3 & $9.1^{\mathrm{a}}$ & 1178 & 2.00 \\
\hline T4 & $8.9^{\mathrm{a}}$ & 1185 & 2.01 \\
\hline T5 & $9.9^{\mathrm{a}}$ & 1179 & 2.00 \\
\hline T6 & $20.8^{\mathrm{b}}$ & 965 & \\
\hline S.E & 0.63 & 11.2 & \\
\hline CD $(0.05)$ & 1.35 & 38.6 & \\
\hline
\end{tabular}

Values are means of four replications

Second season field trial was carried out during kharif 2015 using Coimbatore sunflower Hybrid CO 2 and the sowing was taken up on 10.07.2015 with four replications. The severity of Alternaria leaf spot or blight varied from 4.25 to 17.50 during $50 \mathrm{DAS}$. At $90 \mathrm{DAS}$, Alternaria leaf spot severity varied from 35.17 to 62.72 . The same treatment $\mathrm{T} 2$ recorded the lowest severity of Alternaria leaf spot (35.17). The next best treatment was T3 which recorded the disease severity of 43.20 whereas disease severity was 62.72 in control. The yield was significantly superior in all the treatments over control, the treatment $\mathrm{T} 2$ recorded highest yield of $1766 \mathrm{~kg} /$ ha with B:C ratio of 2.03 followed by treatment 3 which recorded $1428 \mathrm{~kg} / \mathrm{ha}$ with $\mathrm{B}: \mathrm{C}$ ratio of 1.60 as against control which recorded $1129 \mathrm{~kg} / \mathrm{ha}$ with
B:C ratio of 1.30 (Table 2).

Table 2. Management of Alternaria leaf spot/blight through bioagents and fungicides in sunflower - Kharif 2015

\begin{tabular}{|l|l|l|l|}
\hline Treatments & Disease severity (PDI) & Yield (kg/ha) & B:C ratio \\
\hline T1 & $\begin{array}{c}54.92^{\mathrm{d}} \\
(47.83)\end{array}$ & $1273^{\mathrm{bc}}$ & 1.46 \\
\hline T2 & $\begin{array}{c}35.17^{\mathrm{a}} \\
(36.36)\end{array}$ & $1766^{\mathrm{a}}$ & 2.03 \\
\hline T3 & $\begin{array}{l}43.20^{\mathrm{b}} \\
(41.09)\end{array}$ & $1428^{\mathrm{b}}$ & 1.60 \\
\hline T4 & $\begin{array}{c}44.87^{\mathrm{bc}} \\
(42.05)\end{array}$ & $1375^{\mathrm{bc}}$ & 1.52 \\
\hline T5 & $\begin{array}{c}48.75^{\mathrm{c}} \\
(44.28)\end{array}$ & $1373^{\mathrm{bc}}$ & 1.50 \\
\hline T6 & $\begin{array}{c}62.72^{\mathrm{e}} \\
(52.38)\end{array}$ & $1129^{\mathrm{c}}$ & \\
\hline S.E & 1.34 & 134.42 & \\
\hline CD $(0.05)$ & 2.86 & 286.51 & \\
\hline
\end{tabular}

Values are means of four replications and the values in parenthesis are arcsine transformed value

For the third season field trial during kharif 2016, the sowing was taken up on 5.07.2016 with four replications. Alternaria leaf spot severity varied from 33.0 to 59.7 . The same trend was observed in treatment $\mathrm{T} 2$ which recorded the Alternaria leaf spot severity of 33.0 followed by T3 with disease severity of 42.0. The disease severity was 59.7 in control. The yield was significantly superior in all the treatments over control, the treatment $\mathrm{T} 2$ recorded highest yield of $1453 \mathrm{~kg} / \mathrm{ha}$ with B:C ratio of 1.52 followed by treatment T3 which recorded $1379 \mathrm{~kg} / \mathrm{ha}$ with B:C ratio of 1.41 as against control which recorded $1241 \mathrm{~kg} / \mathrm{ha}$ (Table 3). Three years pooled analysis showed that the treatment T2 (seed treatment with Pseudomonas fluorescens (Pf1) @ $10 \mathrm{~g} / \mathrm{kg}$ seeds followed by spray of Hexaconazole @ $0.1 \%$ at 45 days and P. fluorescens (Pf1) @ 1.0\% at 60 DAS) showed less severity of Alternaria leaf spot (25.7) followed by treatment T3 (31.4) against the control (47.7). Further, the same treatment recorded highest yield $(1471 \mathrm{~kg} / \mathrm{ha})$ as against control (1111kg/ha) (Table 4).

In the study, seed biopriming promotes higher and uniform seed germination under filed conditions. Similar results were obtained by Herbar (1991) who reported that that germination and growth of plant were significantly increased in Pseudomonas fluorescens treated seeds when compared to untreated seeds. The growth promoting effect and inhibiton of seed-borne fungi by biocontrol agent is reported by Rao (2006). The efficacy of talc-based BCAs has already been demonstrated on foliar diseases. Beattie and 
Lindow (1995) suggested that $P$. fluorescens might survive on leaf surfaces by occupying particular surface sites. The P. fluorescens (Pf1), Bacillus subtilis (Bs1) are the major potential biocontrol agents against foliar pathogens. MPf1 and MBs1 were found to be most effective in inhibiting the mycelial growth of Alternaria helianthi (Ahila Devi et al., 2014).

Table 3. Management of Alternaria leaf spot/blight through bioagents and fungicides in sunflower - Kharif 2016

\begin{tabular}{|l|l|l|l|}
\hline Treatments & Disease severity (PDI) & Yield (kg/ha) & B:C ratio \\
\hline T1 & $\begin{array}{l}45.8^{\mathrm{b}} \\
(42.60)\end{array}$ & 1364 & 1.44 \\
\hline T2 & $\begin{array}{l}33.0^{\mathrm{a}} \\
(35.08)\end{array}$ & 1453 & 1.52 \\
\hline T3 & $\begin{array}{l}42.0^{\mathrm{b}} \\
(40.44)\end{array}$ & 1379 & 1.41 \\
\hline T4 & $\begin{array}{l}43.6^{\mathrm{b}} \\
(41.33)\end{array}$ & 1347 & 1.36 \\
\hline T5 & $\begin{array}{l}45.7^{\mathrm{b}} \\
(41.97)\end{array}$ & 1306 & 1.31 \\
\hline T6 & $\begin{array}{l}59.70^{\mathrm{c}} \\
(50.61)\end{array}$ & 1241 & \\
\hline S.E & 1.16 & 135.79 & \\
\hline CD $(0.05)$ & 2.47 & 289.43 & \\
\hline CV \% & 3.91 & 14.24 & \\
\hline
\end{tabular}

Values are means of four replications and the values in parenthesis are arcsine transformed value

Table 4. Management of Alternaria leaf spot/blight through bioagents and fungicides in sunflower (pooled analysis of 3 years data)

\begin{tabular}{|c|c|c|c|c|}
\hline Treatments & \multicolumn{2}{|c|}{$\begin{array}{l}\text { Disease severity } \\
\text { (PDI) }\end{array}$} & \multicolumn{2}{|c|}{ Yield (kg/ha) } \\
\hline $\mathrm{T} 1$ & \multicolumn{2}{|c|}{36.9} & \multicolumn{2}{|l|}{1271} \\
\hline $\mathrm{T} 2$ & \multicolumn{2}{|l|}{25.7} & \multicolumn{2}{|l|}{1471} \\
\hline $\mathrm{T} 3$ & \multicolumn{2}{|l|}{31.4} & \multicolumn{2}{|l|}{1328} \\
\hline $\mathrm{T} 4$ & \multicolumn{2}{|l|}{32.4} & \multicolumn{2}{|l|}{1302} \\
\hline T5 & \multicolumn{2}{|l|}{34.4} & \multicolumn{2}{|l|}{1286} \\
\hline \multirow[t]{2}{*}{ T6 } & \multicolumn{2}{|l|}{47.7} & \multicolumn{2}{|l|}{1111} \\
\hline & S.E & $\mathrm{CD} @ 0.05$ & S.E & $\mathrm{CD} @ 0.05$ \\
\hline Treatment & 0.74 & $2.11 *$ & 45.32 & $128.82 *$ \\
\hline Seasons & 0.52 & $1.49^{*}$ & 32.04 & $91.09 *$ \\
\hline Seasons x Treatment & 1.28 & $3.65^{*}$ & 78.49 & $223.13 \mathrm{~ns}$ \\
\hline $\mathrm{CV} \%$ & \multicolumn{2}{|l|}{7.39} & \multicolumn{2}{|l|}{12.12} \\
\hline
\end{tabular}

The result of the three years pooled analysis showed that seed priming with Pseudomonas fluorescens (Pf1) @10 $\mathrm{g} / \mathrm{kg}$ seeds followed by spray of Hexaconazole @ $0.1 \%$ at 45 days and P.fluorescens (Pf1) @ 1.0\% at 60 DAS) showed less severity of Alternaria leaf spot (25.7) with the highest yield of $1471 \mathrm{~kg} / \mathrm{ha}$. In the field trials, (rainy season of the years 2009-10 and 2010-11), seed treatment, foliar application of T. harzianum Th4d SC at $2 \mathrm{ml} / 1$ and consortium for- mulations (T. harzianum $\mathrm{Th} 4 \mathrm{~d} \mathrm{SC}+$ T. asperellum $\mathrm{Tv} 5 \mathrm{SC}$ at $1 \mathrm{ml} / \mathrm{l}$ ) effectively reduced the severity of the disease (ALB reduction up to $50-55 \%$ and BGM up to $55-65 \%$ ). In addition, these applications enhanced sunflower and castor yield compared to untreated control (Navaneetha et al., 2014). P. fluorescens and T. harzianum followed by B. subtilis treatment showed higher peroxidases activity over control are associated with stages of the infection process and are involved in generation of hydrogen peroxidase which inhibit the pathogen directly by producing free radicles having antimicrobial activity and lignification (Hammerschmidt et al., 1982).

Hence our studies indicate that seed treatment with Pseudomonas fluorescens (Pf1) @ 10g/kg seeds followed by spray of Hexaconazole @ $0.1 \%$ at 45 days and P. fluorescens (Pf1) @1.0\% at 60 DAS is effective for the management of Alternaria leaf spot or blight in sunflower crop.

\section{REFERENCES}

Alves JL, Woudenberg JHC, Duarte LL, Crous PW, Barreto RW. 2013. Reappraisal of the genus Alternariaster (Dothideomycetes). Persoonia 31: 77-85. DOI: 10.3767/003158513X669030. Crossref

Devi A, Mohan PS, Rajalakshmi J. 2014. Growth promotion activity and biological control for the management of leaf blight incited by Alternaria helianthi. Arch. Phyopath Pl Prot. 47(18): 2280-2287. Crossref

Arunakumara KT, Kulkarni MS, Thammaiah N, Yashoda H. 2010. Fungicidal management of early blight (Alternaria solani) of tomato. Indian Phytopathol. 63(1): 96-97

Balasubrahmanyam N, Kolte SJ. 1980. Effect of Alternaria blight on yield components, oil content and seed quality of sunflower. Indian J Agric Sci. 50: 701-706.

Beattie GA, Lindow SE. 1995. The secret life of foliar bacterial pathogens on leaves. Annu Rev Phytopathol. 33: 145-172. Crossref PMid:18294082

Chander Rao S, Sujatha M, Karuna K, Varaprasad KS. 2015. Powdery mildew disease in sunflower : A review. J Oilseeds Res. 32(1): 111-122

Ganesan S, Ganesh Kuppusamy R, Sekar R. 2007. Integrated management of stem rot disease (Sclerotium rolfsii) of groundnut (Arachis hypogaea L.) using Rhizobium and Trichoderma harzianum (ITCC - 4572). Turk $J$ Agric. 31: 103-108. 
Gomez KA, Gomez AA. 1984. Statistical procedure for agricultural research. John Wiley and Sons, New York.

Hammerschmidt R, Nucldes EM, Kuc J. 1982. Association of enhanced peroxidase activity with induced systemic resistance of cucumber to Colletotrichum lagenarium. Physiol Mol Plant Pathol. 20: 73-82. Crossref

Jeffrey F. 1984. Seed treatment fungicides for control of seed borne Alternaria helianthi on sunflower. Pl. Dis. 69(2): 124-126. Crossref

Leite RMVBC, Amorim L. 2002. Elaboração e validação deescala diagramática para mancha de Alternaria em girassol. Summa Phytopathol. 28: 14-19.

Mathivanan N, Prabavathy VR. 2007. Effect of carbendazim and mancozeb combination on Alternaria leaf blight and seed yield of sunflower. Arachis Phytopathol Plant Protect. 40(2): 90-96. Crossref

Mesta RK, Sunkad G and Katti P. 2003. Chemical control of alternaria blight of sunflower. In: Proceedings of the National Seminar on Stress Management in Oilseeds - Attaining Self Reliance Vegetable Oils, January 28 - 30, Directorate of Oilseeds Research, Hyderabad, p. 149-151. PMid:12615394

Navaneetha T, Prasad RD, Venkateswar Rao L. 2014. Liquid Formulation of Trichoderma Species for Management of Gray mold in Castor (Ricinus communis L.) and Alternaria Leaf Blight in Sunflower (Helianthus annuus L.) J Biofertil Biopest. 6:1

Prathuangwong S, Kao SW, Sommartya T, Sinchaisri P. 1991. Role of four Alternaria spp. causing leaf and stem blight of sunflower in Thailand and their chemical controls. Kasetsart J. 25: 112-124.
Rao MSL. 2006. Studies on seed borne fungal diseases of sunflower and their management. Ph.D. Thesis, University of Agricultural Sciences, Dharwad pp. 55-90.

Ramakrishnan B, Kamalanathan K, Krishnamurthy CS. 1971. Studies on Alternaria leaf spot of tomato. Madras Agric J. 158: 275-280.

Rao MA, Nageshwar Rao TG. 1997. Management of sunflower Alternaria blight [Alternaria helianthi (Hansf.)] IPS golden jubilee International Conference on Integrated Plant Diseases Management for Sustainable Agriculture held on 10-15, Nov., 1997, New Delhi, India, pp. 359.

Reddy PC, Gupta BM. 1977. Disease loss appraisal due to leaf blight of sunflower indicated by Alternaria helianthi. Indian Phytopathol. 30: 569-570.

Singh HK, Singh RB. 2007. Integrated management of Alternaria blight of Rapeseed-mustard. Indian Phytopathol. 60(3): 396.

Shirshikar SP. 2008. Integrated management of sunflower Necrosis disease. HELIA 31(49): 27-34. Crossref

Waghe KP, Wagh SS, Kuldhar DP, Pawar DV. 2015. Evaluation of different fungicides, bioagents and botanicals against Alternaria blight caused by Alternaria helianthi (Hansf) of sunflower. Afr J Agric Res. 10(5): 351-358

Wang T, Zhao J, Sun P, Wu X. 2014. Characterization of Alternaria species associated with leaf blight of sunflower in China. Eur J Plant Pathol. 140: 301. doi:10.1007/s10658-014-0464-z Crossref 